\author{
Michalina KaSPRZAK ${ }^{1}$ \\ Uniwersytet im. Adama Mickiewicza \\ $w$ Poznaniu
}

\title{
THE OPPORTUNITIES \\ FOR DEVELOPMENT OF THE CHILD'S CREATIVE POTENTIAL IN LOCAL INSTITUTIONS
}

\begin{abstract}
Aвstract. Kasprzak Michalina, The Opportunities for Development of the Child's Creative Potential in Local Institutions [Możliwości rozwoju potencjału twórczego dziecka w instytucjach lokalnych]. Studia Edukacyjne nr 48, 2018, Poznań 2018, pp. 295-302. Adam Mickiewicz University Press. ISSN 1233-6688. DOI: $10.14746 /$ se.2018.48.19

In this article, the main goal is to present on the basis of own scientific observations different principles of developing the child's creative potential. The author presents three elements: encouraging, identifying and fostering in the context of child's creative potential and then she presents three perspective of opportunities for development child's creative potential in the local institutions for children. In summary she write a short concept about the opportunities for development to creativity of each child from the disfavoured backgrounds.
\end{abstract}

Key words: creative potential, creativity, child development, local institution, non-formal education

If you want to be creative, stay in part a child, with the creativity and invention that characterizes children before they are deformed by society.

Jean Piaget $^{2}$

\section{Introduction}

The child's creative development in pedagogical and psychological literature is most often discussed in the context of supporting a pupil in school or

\footnotetext{
${ }^{1}$ Michalina Kasprzak is Adam Mickiewicz University Foundation scholar in 2017/2018 academic year.

${ }^{2}$ M. Mayesky, Creative Activities for Young Children, Belmont CA 2012, p. 19.
} 
kindergarten education, by teachers and parents. Definitely there are people, who are needed in the multi-aspect development of the child, but not only they could create opportunities for development of the child's creative potential. Actually, supporting and developing the opportunities for development of the child's creative potential applies to every person who works with him. In addition, external and internal factors (independent of the child's caregivers) also influence for the development of the creative potential.

Recently there have been many publications about the creative teacher, student and also the parent. In addition to reliable scientific publications eg. "Creative Education", ${ }^{3}$ or "Creativity: Theories-Research-Application$\mathrm{s}^{\prime \prime},{ }^{4}$ (with the theoretical and empirical part), also they are very often guides, whose are popular-scientific or pseudoscientific, addressed to a specific group of recipients (they are not supported by any theoretical or empirical research). In simple terms, their main task is to provide the ideal model of creative child education. In my opinion, the search for an 'ideal pattern' in this area is a work without a result, because there is a lot of concepts for understanding creativity, and is also considered in various areas and subdisciplines (not only pedagogical and psychological). In order not to get lost in the sciences of creativity, one should discern in the literature and subject of interest. ${ }^{5}$

Nowadays, problems in making the subject of developing the creative potential of a child are not focused solely on terminology. One of the still-current problems is understanding the creativity place in education, ${ }^{6}$ and also that in education and view of developing the creative potential of children, people connect the themes of creativity with art or individual fields of art (eg. plastic art, music, sculpture), in which fields children are talented or not. ${ }^{7}$ In addition, the problems are also myths about the harmful influence of media on the authenticity and presence of creativity in media (eg. online creativity, net-art). ${ }^{8}$ As well as myths, about greater creative potential in younger children than in older children. Naturally, a child needs creative activity to explore the world. ${ }^{9}$ However, from my perspective, we should start thinking about creativity as a common good - as, eg., about security or freedom in the world..$^{10}$ Then our at-

${ }^{3}$ https://www.scirp.org/journal/ce/

${ }^{4}$ http://creativity.uwb.edu.pl/index.php/en/

${ }^{5}$ An example of consolidation of knowledge about the development of creativity can be the book by K. Szmidt, ABC Kreatywności, Warszawa 2010.

${ }^{6}$ E. Prijatelj, The Understanding of Creativity and its Place in Education, [in:] Education and Creativity, Ed. E. Osewska, Warszawa 2014, p. 13-20.

7 J. McFarlane, Supporting children's development, Extract from Putting Children First, the magazine of the National Childcare Accreditation Council (NCAC), 2008, 27, p. 6-9.

${ }^{8}$ M.A. Boden, Creativity and Art. Three Roads to Surprise, New York 2010, p. 193-209.

${ }^{9}$ R. Gloton, C. Clero, Twórcza aktywność dziecka, Warszawa 1976, p. 57-60.

10 R. Florida, The Flight of the Creative Class. The New Global Competition for Talent, New York 2005, p. 269. 
tention will be focused on stimulating child's development, strengthening his creative potential, supporting his challenges and more. Thinking in this way, we should start with the fact that not every child has an equal start. Equality in education - in my opinion one element is missing: cooperation. ${ }^{11} \mathrm{~A}$ child, parent, family, school, peer environment, local environment and community should cooperate for more effective work. ${ }^{12}$ However, cooperation can exist if all of its entities accept each other.

\section{The Creative Power of Local Institutions}

Teaching in the educational process can be divided into teaching creatively or teaching for creativity. Creatively teaching is not the same as teaching for creativity, because the child's contribution to self-development is important. ${ }^{13}$ In my opinion, among others in Poland, we are just beginning to think about teaching to creativity. Education in Poland and many other countries is very schematic (eg. tests after each educational stage), so we should teach children for creativity not only in the school education process. Especially because, children from different backgrounds participate in the lessons at school, and equality in education (eg. for development of child's creative potential) should be available for each child. It is very difficult to work at different levels of developing individual child's capabilities in such a diverse environment. One of the proposals to focus the activities on the group of children who come from disfavoured backgrounds (which need special support in multifaceted development) is work in local institutions.

Activity of local institutions called also 'local centers' for children is oriented to help and support the overall development of children, who come from disfavoured backgrounds, which means, they come especially from families with social problems, from families with risk of social exclusion or already excluded..$^{14}$ Depending on the needs, help can be given to children, but also to their parents. Usually, children attend classes regularly (eg. every day, several times a week), and meetings for parents take place regularly (eg. once a month). Participation in the local institution/local center is voluntary and free for children and their families, usually are conducted with funding from the Municipal Office or non-governmental organizations. These are places where participation is voluntary and free for children and their families, and

${ }^{11}$ K. Sawyer, Group Genius. The Creative Power of Collaboration, New York 2007, p. 74.

${ }_{12}$ W.D. Wall, Twórcze wychowanie w okresie dzieciństwa, Warszawa 1986, p. 18.

${ }^{13}$ K.J. Szmidt, Pedagogika twórczości, Sopot 2013, p. 26-27.

${ }^{14}$ M. Czechowska-Bieluga, Social distance between Professional helpers/social workers and social assistance clients, [in:] Socio-pedagogical Contexts of Social Marginalization, Eds. S. Byra, E. Chodkowska, Lublin 2013, p. 177-200. 
also children's free time is organized, eg.: children can be several hours a day and then return to their family home; they are under the care of the educator; activities in the institutions/centers are held after school; the centers are out-of-school forms in the local space (it means that they do not carry out the school program); children receive a meal; children work in groups and individually; in the local institution/center is a concentration on the child and his needs. ${ }^{15}$

In this part of the paper I would like to present the results of observations in local institutions for children, gathered in stages (over three years) from institutions in San Alberto (Paraguay), Tarragona (Spain) and Poznan (Poland). In each city, the observation was carried out by me (in person), each day according to a specific pattern. First of all, I searched for the answer to the question: Do children have opportunities to develop their creative potential in local institutions? Taking into account the space of place (institution), the child's space and the space of educator. I considered all dimensions of space in the perspective of teaching creatively. I adopted the following pattern of thinking about the three basic areas of creative space. First of all, I was interested in the following activities: encouraging, identifying and fostering. ${ }^{16}$ Another very important element was the social context of creativity ${ }^{17}$ (especially the family environment and the local community), because children attending local institutions in each researched city came from disfavoured families.

\section{The first view: the space of place}

The spacious space inside and outside would be fostering to development of the child's creative potential in local institutions, eg. outside the institution should be a place to outdoor playground and on the inside spacious room with desks and chairs. Sometimes with carpets and things that make for a better atmosphere in room. If the space is friendly then children have the opportunity to lern with all of the senses.

In San Alberto, the local institution for children was conducted by the parish. Financing depended on local residents and the church council. There were three classes available with desks, chairs, tables and educational materials. Additionally, one class with a TV. In addition, there was a kitchen and

${ }^{15}$ Ustawa z 9 czerwca 2011 roku o wspieraniu rodziny i systemie pieczy zastępczej, DzU 2013, poz. 135, z późn. zm., art. 18-24.

${ }_{16}$ Based on the report of National Advisory Commitee on Creative and Cultural Education (NACCCE): All our futures. Creativity, culture and education, London, DfEE 1999, p. 102-104. Comparison with: A. Craft, B. Jeffrey, M. Libeling (Eds.), Creativity in education, Continuum, London - New York 2001; K. Szmidt, Pedagogika twórczości, Sopot 2013.

${ }^{17}$ E. Nęcka, Psychologia twórczości, Sopot 2012, p. 154-182. 
bathroom. Outside, under the roof, there was a large square with a stage, tables and benches.

In Tarragona, the local institution for children was conducted in a building of cultural center, but in the social department. Financing depended on Muncipal Office, from social manager and local sponsors. There were two classes available with desks, chairs, tables and educational materials. Additionally, two gymnastic classes and also a large room with a stage. Furthermore big kitchen with dining room, chairs and benches and also bathrooms. The outside was a large outdoor playground.

In Poznan the local institution for children was conducted by the NonGovernmental Organization. Financing depended on Muncipal Office, from European Union projects and from local sponsors. There were one classes available with desks, chairs, computers and educational materials. Additionally, one room like office. Furthermore small kitchen with corridor. No space outside.

In each institution, educators were able to manage the place. However, despite this, space created barriers to developing of child's creative potential. In San Alberto, eg., the problem was created by a large, roofed outdoor hall, where children were very quickly distracted and running. There was no fence, there was a risk of accident. In Tarragona space conditions were very favorable for the child and its development. The rooms had adapted desks and chairs for younger children, separately for older children. If necessary, there was access to rooms with more space, and gyms or outside the building. The institution in Poznan had the least space. It was often crowded, but the security rules were kept. The problem was also lack of space outside. If was necessary, outdoor activities took place on a local pitch.

\section{The second view: the child's space}

Everyone has creative potential that can be triggered and developed..$^{18}$ Children also have creative potential, but especially children who do not receive motivation, support and help in their family and school environment, they do not know their potential, which they have.

From birth, children explore and understand their world through touching, seeing, hearing and responding to colours, textures, sights and sounds in their environment. It is from these early explorations that lifelong attitudes about creativity and our own capacity to be creative are formed. ${ }^{19}$

\footnotetext{
${ }^{18}$ Ibidem, p. 19-21.

${ }^{19}$ J. McFarlane, Supporting children's development, p. 6.
} 
Therefore, it is important that when observing a child, look at his exploration of the world through three elements: character traits, emotional processes and cognitive abilities.

In the observed institutions, children presented diverse problems originating from home, school, peer relationships, etc. but despite some disorders, they always undertook creative activity. Creating them an atmosphere of motivation, support and help by educators provided many opportunities to developing the child's creative potential, eg. when they do homework, when they construct own speeches, when they do exercises with group, when they play with someone, when they planning and building a performance for guests, when they creating performance's scenography or creating artworks and drawings, etc. Children always showed joy of activities, from being in a group, and also showed their willingness to expand knowledge, and joy of combating existing barriers (including school failures).

Among other things, scientific research G. Krumm, J. Vergas Rubilar, V. Lemos, L. Oros ${ }^{20}$ about perception of creativity in children parents and peers: effect on creative production, shows that

in relation to the perception of peers about the creativity of the partner and its effect on creative production, it was found that those children who are recognized as creative partners score better in the creative production made through drawings. ${ }^{21}$

From my perspective this is important, because being creative involves nurting our interest, expressing our ideas and working with others to come up with solutions to every problems.

\section{The third view: the space of educator}

The educator have a really important role in the process of child's creative potential development. In the local centers are children who are experiencing school failures or gifted children (from the families with social problems). They especially need encouraging, supporting and care and also help from educators. Educators should remember:

creativity is an important human characteristic. It is perhaps best thought of as a process, requiring a mixture of ingredients, including personality traits, abilities and skil1s. Early years staff can help young children to develop their creativity by providing

${ }^{20}$ G. Krumm et al., Percepción de la creatividad en niños, padres y pares: efectos en la producción creativa, Pensamiento Psicológico, 2015, 13, 2, p. 21-32.

${ }^{21}$ Ibidem, p. 28. 
a creative environment, helping children to build up their skills through play, behaving creatively themselves and praising children's creative efforts. ${ }^{22}$

Educators from the observed institutions had the appropriate education to work with children. In Tarragona and Poznan, they also had completed courses that gathered their knowledge and skills to work in a difficult environment. When I observed their work, they often showed professionalism, especially in the most difficult situations (eg child aggression attack, family mediation). First of all, their attitudes were very open and accepting all participants of the classes, focused on the child's development and help him find a way for him's creative potential.

\section{Summary}

In my opinion, there are opportunities to develop the creative potential of children, especially those who come from disfavoured backgrounds in local institutions. Above I have presented examples confirming the importance of the functioning of local institutions in society.

However, it depends on whether the adult is interested in the development of the child and wants to cooperate with other entities for the child. The parent must consent to the child's participation in any classes, and also should be involved. In order to involve other people in the context for development of child's creative potential, not only the will to cooperate is necessary, but also the establishment of new educational solutions. One of proposition for that is the key whose is paradox, because: "just enough focus so that team members can tell when they get closer to a solution - but one that's open-ended enough for problem-finding creativity to emerge" ${ }^{23}$ I hope will be more places when the workers will think about the child and his creative potential, and they will plan their work to motivate, support and help children in recognizing their own creative abilities, which nowadays are really important skills.

\section{BIBLIOGRAPHY}

Boden M.A., Creativity and Art. Three Roads to Surprise, Oxford University Press, New York 2010.

Byra S., Chodkowska E. (Eds.), Socio-pedagogical Contexts of Social Marginalization, Maria Curie-Skłodowska Univeristy Press, Lublin 2013.

${ }^{22}$ C. Sharp, Developing young children's creativity: what can we learn from research? Topic, 2012, 32, p. 9.

${ }^{23}$ K. Sawyer, Group Genius. The Creative Power of Collaboration, New York 2007, p. 35. 
Craft A., Jeffrey B., Libeling M. (Eds.), Creativity in education, Continuum, London - New York 2001.

Czechowska-Bieluga M., Social distance between Professional helpers/social workers and social assistance clients, [in:] Socio-pedagogical Contexts of Social Marginalization, Eds. S. Byra, E. Chodkowska, Maria Curie-Skłodowska Univeristy Press, Lublin 2013.

Florida R., The Flight of the Creative Class. The New Global Competition for Talent, Harper Business, New York 2005.

Gloton R., Clero C., Twórcza aktywność dziecka, Wydawnictwa Szkolne i Pedagogiczne, Warszawa 1976.

Krumm G., Vergas Rubilar J., Lemos V., Oros L., Percepción de la creatividad en niños, padres y pares: efectos en la producción creative, Pensamiento Psicológico, 2015, 13, 2.

Mayesky M., Creative Activities for Young Children, Wadsworth Cengage Learning, Belmont CA 2012.

McFarlane J., Supporting children's development, Extract from Putting Children First, the magazine of the National Childcare Accreditation Council (NCAC), 2008, 27.

Nęcka E., Psychologia twórczości, Gdańskie Wydawnictwo Psychologiczne, Sopot 2012.

Osewska E. (Ed.), Education and Creativity, Wydawnictwo Uniwersytetu Kardynała Stefana Wyszyńskiego, Warszawa 2014.

Prijatelj E., The Understanding of Creativity and its Place in Education, [in:] Education and Creativity, Ed. E. Osewska, Wydawnictwo Uniwersytetu Kardynała Stefana Wyszyńskiego, Warszawa 2014.

Report of National Advisory Commitee on Creative and Cultural Education (NACCCE), All our futures. Creativity, culture and education, DfEE, London 1999.

Sawyer K., Group Genius. The Creative Power of Collaboration, Basic Books, New York 2007.

Sharp C., Developing young children's creativity: what can we learn from research? Topic, 2004, 32.

Szmidt K.J., ABC kreatywności, Wydawnictwo Difin, Warszawa 2010.

Szmidt K.J., Pedagogika twórczości, Gdańskie Wydawnictwo Psychologiczne, Sopot 2013.

Ustawa z 9 czerwca 2011 roku o wspieraniu rodziny i systemie pieczy zastępczej, DzU 2013, poz. 135 z późn. zm.

Wall W.D., Twórcze wychowanie w okresie dzieciństwa, Państwowe Wydawnictwo Naukowe, Warszawa 1986.

https://www.scirp.org/journal/ce/

http://creativity.uwb.edu.pl/index.php/en/ 